\title{
An experimental and modeling study on the
}

\section{pretreatment and alkaline hydrolysis of blue}

\section{agave bagasse in twin-screw extruders}

Juan Carlos Morales-Huerta, ${ }^{[a]}$ Oscar Hernández-Meléndez, ${ }^{[a]}$ Martín Guillermo

Hernández-Luna, ${ }^{[a]}$ Octavio Manero, ${ }^{[b]}$ Eduardo Bárzana, ${ }^{[c]}$ and Eduardo Vivaldo-

$\operatorname{Lima}^{*[a]}$.

${ }^{[a]}$ Facultad de Química, Departamento de Ingeniería Química, Universidad Nacional

Autónoma de México, CU, 04510, México City, México, E-mail: vivaldo@unam.mx

${ }^{[b]}$ Instituto de Investigaciones en Materiales, Universidad Nacional Autónoma de México,

CU, 04510, México City, México

${ }^{[c]}$ Facultad de Química, Departamento de Alimentos y Biotecnología, Universidad Nacional Autónoma de México, CU, 04510, México City, México 
S1. Screw Elements and Configuration

Table S1. Nomenclature and characteristics of the screw elements used in this study

\begin{tabular}{llllll}
\hline Name $^{\mathrm{a}}$ & Geometry & Direction & Pitch $(\mathrm{mm})$ & $\begin{array}{l}\text { Length } \\
(\mathrm{mm})\end{array}$ & Representation \\
$\mathrm{C} 2 \mathrm{~F}$ & $\begin{array}{l}\text { Conveying } \\
\text { double- } \\
\text { thread screw }\end{array}$ & Direct & 30 & 30 & 15 \\
$\mathrm{C} 1 \mathrm{~F}$ & $\begin{array}{l}\text { Conveying } \\
\text { single screw }\end{array}$ & Direct & 15 & 15 & \\
$\mathrm{KD}$ & $\begin{array}{l}\text { Kneading } \\
\text { disc }\end{array}$ & Direct & 18 & 15 & \\
$\mathrm{CF} 1 \mathrm{C}$ & $\begin{array}{l}\text { Counter-flux } \\
\text { single screw }\end{array}$ & Inverse & 15 & 15 & \\
\hline
\end{tabular}

${ }^{\mathrm{a} D i a m e t e r}$ of the elements: $30 \mathrm{~mm}$. 
Table S2. Screw configurations used in the different experiments carried out in the TSE

\begin{tabular}{lllllllllll}
\hline Experiment 1 (Fig. S2) & 110 \\
\hline Module & 1 & 2 & 3 & 4 & 5 & 6 & 7 & 8 & 9 & 10 \\
\hline \multirow{2}{*}{ Screw } & $\mathrm{C} 1 \mathrm{~F}$, & $\mathrm{C} 2 \mathrm{~F}$, & $\mathrm{C} 2 \mathrm{~F}$, & $\mathrm{C} 2 \mathrm{~F}$, & $\mathrm{C} 2 \mathrm{~F}$, & $\mathrm{C} 2 \mathrm{~F}$, & $\mathrm{C} 2 \mathrm{~F}$, & $\mathrm{C} 2 \mathrm{~F}$, & $\mathrm{C} 2 \mathrm{~F}$, & $\mathrm{C} 2 \mathrm{~F}$, \\
element & $\mathrm{C} 2 \mathrm{~F}$, & $\mathrm{C} 2 \mathrm{~F}$, & $\mathrm{C} 2 \mathrm{~F}$, & $\mathrm{C} 2 \mathrm{~F}$, & $\mathrm{C} 2 \mathrm{~F}$, & $\mathrm{C} 2 \mathrm{~F}$, & $\mathrm{C} 2 \mathrm{~F}$, & $\mathrm{C} 2 \mathrm{~F}$, & $\mathrm{C} 2 \mathrm{~F}$, & $\mathrm{C} 2 \mathrm{~F}$, \\
& $\mathrm{C} 2 \mathrm{~F}$, & $\mathrm{C} 2 \mathrm{~F}$, & $\mathrm{C} 2 \mathrm{~F}$, & $\mathrm{C} 2 \mathrm{~F}$, & $\mathrm{C} 2 \mathrm{~F}$, & $\mathrm{C} 2 \mathrm{~F}$, & $\mathrm{C} 2 \mathrm{~F}$, & $\mathrm{C} 2 \mathrm{~F}$, & $\mathrm{CF} 1 \mathrm{C}$, & $\mathrm{C} 2 \mathrm{~F}$, \\
& $\mathrm{C} 2 \mathrm{~F}$ & $\mathrm{C} 2 \mathrm{~F}$ & $\mathrm{C} 2 \mathrm{~F}$ & $\mathrm{C} 2 \mathrm{~F}$ & $\mathrm{C} 2 \mathrm{~F}$ & $\mathrm{C} 2 \mathrm{~F}$ & $\mathrm{C} 2 \mathrm{~F}$ & $\mathrm{C} 2 \mathrm{~F}$ & $\mathrm{CF} 1 \mathrm{C}$ & $\mathrm{C} 2 \mathrm{~F}$ \\
\end{tabular}

Experiments 2-4 (Fig. 2) and 5 (Fig. 3)

\begin{tabular}{|c|c|c|c|c|c|c|c|c|c|c|}
\hline Module & 1 & 2 & 3 & 4 & 5 & 6 & 7 & 8 & 9 & 10 \\
\hline $\begin{array}{l}\text { Screw } \\
\text { element }\end{array}$ & $\begin{array}{l}\mathrm{C} 1 \mathrm{~F}, \\
\mathrm{C} 2 \mathrm{~F}, \\
\mathrm{C} 2 \mathrm{~F}, \\
\mathrm{C} 2 \mathrm{~F}\end{array}$ & $\begin{array}{l}\mathrm{C} 2 \mathrm{~F}, \\
\mathrm{KD}, \\
\mathrm{KD}, \\
\mathrm{C} 2 \mathrm{~F}\end{array}$ & $\begin{array}{l}\mathrm{C} 1 \mathrm{~F}, \\
\mathrm{C} 2 \mathrm{~F}, \\
\mathrm{C} 2 \mathrm{~F}, \\
\mathrm{C} 2 \mathrm{~F}\end{array}$ & $\begin{array}{l}\mathrm{C} 2 \mathrm{~F}, \\
\mathrm{C} 2 \mathrm{~F}, \\
\mathrm{C} 2 \mathrm{~F} \\
\mathrm{C} 1 \mathrm{~F}\end{array}$ & $\begin{array}{l}\mathrm{C} 2 \mathrm{~F}, \\
\mathrm{C} 2 \mathrm{~F}, \\
\mathrm{C} 2 \mathrm{~F}, \\
\mathrm{C} 1 \mathrm{~F}\end{array}$ & $\begin{array}{l}\mathrm{C} 1 \mathrm{~F}, \\
\mathrm{C} 2 \mathrm{~F}, \\
\mathrm{C} 2 \mathrm{~F}, \\
\mathrm{C} 2 \mathrm{~F}\end{array}$ & $\begin{array}{l}\mathrm{KD}, \\
\mathrm{KD}, \\
\mathrm{C} 2 \mathrm{~F}, \\
\mathrm{C} 2 \mathrm{~F}\end{array}$ & $\begin{array}{l}\mathrm{C} 2 \mathrm{~F}, \\
\mathrm{C} 2 \mathrm{~F}, \\
\mathrm{C} 2 \mathrm{~F}, \\
\mathrm{C} 1 \mathrm{~F}\end{array}$ & $\begin{array}{l}\mathrm{C} 2 \mathrm{~F}, \\
\mathrm{C} 2 \mathrm{~F}, \\
\mathrm{CF} 1 \mathrm{C}, \\
\mathrm{CF} 1 \mathrm{C}\end{array}$ & $\begin{array}{l}\mathrm{C} 2 \mathrm{~F}, \\
\mathrm{C} 2 \mathrm{~F}, \\
\mathrm{C} 1 \mathrm{~F}, \\
\mathrm{C} 1 \mathrm{~F}\end{array}$ \\
\hline \multicolumn{11}{|c|}{ Experiments 6-18 (Fig. 4a, 4b, 4c, 5, 6a, 6b, 7a, 7b, 8, 9a, 9b, 9c) } \\
\hline Module & 1 & 2 & 3 & 4 & 5 & 6 & 7 & 8 & 9 & 10 \\
\hline $\begin{array}{l}\text { Screw } \\
\text { element }\end{array}$ & $\begin{array}{l}\mathrm{C} 2 \mathrm{~F}, \\
\mathrm{C} 2 \mathrm{~F}, \\
\mathrm{C} 2 \mathrm{~F}, \\
\mathrm{C} 2 \mathrm{~F}\end{array}$ & $\begin{array}{l}\mathrm{C} 2 \mathrm{~F}, \\
\mathrm{KD}, \\
\mathrm{KD}, \\
\mathrm{C} 2 \mathrm{~F}\end{array}$ & $\begin{array}{l}\mathrm{C} 2 \mathrm{~F}, \\
\mathrm{C} 2 \mathrm{~F}, \\
\mathrm{C} 2 \mathrm{~F}, \\
\mathrm{C} 2 \mathrm{~F}\end{array}$ & $\begin{array}{l}\mathrm{C} 2 \mathrm{~F}, \\
\mathrm{C} 2 \mathrm{~F}, \\
\mathrm{C} 2 \mathrm{~F}, \\
\mathrm{C} 2 \mathrm{~F}\end{array}$ & $\begin{array}{l}\mathrm{C} 2 \mathrm{~F}, \\
\mathrm{C} 2 \mathrm{~F}, \\
\mathrm{C} 2 \mathrm{~F}, \\
\mathrm{C} 2 \mathrm{~F}\end{array}$ & $\begin{array}{l}\mathrm{C} 2 \mathrm{~F}, \\
\mathrm{C} 2 \mathrm{~F}, \\
\mathrm{C} 2 \mathrm{~F}, \\
\mathrm{C} 2 \mathrm{~F}\end{array}$ & $\begin{array}{l}\mathrm{KD}, \\
\mathrm{KD}, \\
\mathrm{C} 2 \mathrm{~F}, \\
\mathrm{C} 2 \mathrm{~F}\end{array}$ & $\begin{array}{l}\mathrm{C} 2 \mathrm{~F}, \\
\mathrm{C} 2 \mathrm{~F}, \\
\mathrm{C} 2 \mathrm{~F}, \\
\mathrm{C} 2 \mathrm{~F}\end{array}$ & $\begin{array}{l}\mathrm{C} 2 \mathrm{~F}, \\
\mathrm{C} 2 \mathrm{~F}, \\
\mathrm{CF} 1 \mathrm{C}, \\
\mathrm{CF} 1 \mathrm{C}\end{array}$ & $\begin{array}{l}\mathrm{C} 2 \mathrm{~F}, \\
\mathrm{C} 2 \mathrm{~F}, \\
\mathrm{C} 2 \mathrm{~F}, \\
\mathrm{C} 2 \mathrm{~F}\end{array}$ \\
\hline
\end{tabular}


S2. Modeling issues

a) Correlations between lignin content and extracted hemicellulose and cellulose
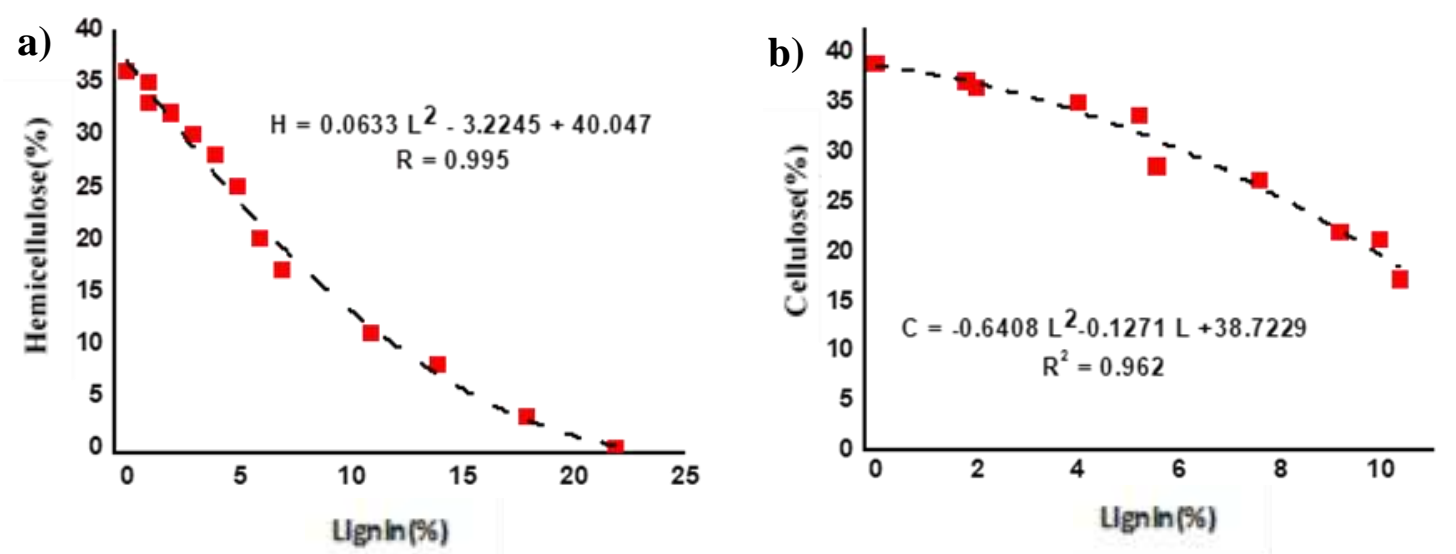

Figure S1. Correlations between lignin content and a) extracted hemicellulose, and b) extracted cellulose, using experimental data from Qiabi et al. ${ }^{44}$ and Fuertez et al. ${ }^{47}$, respectively.

b) Numerical issues

The calculation sequence is described below and summarized in Figure S2.

\section{1) Start}

2) Input of physical and chemical data: Values of $\mathrm{NaOH}$ concentration, $\mathrm{L} / \mathrm{S}$ ratio and composition of BAB (L, H and C) should be introduced:
a. $\mathrm{NaOH}$ concentration
b. $\mathrm{L} / \mathrm{S}$ ratio
c. L, $\mathrm{H}$ and $\mathrm{C}$ content in Blue Agave Bagasse (BAB)

\section{3) Input of operational data:}

a. Geometrical configuration (GC): The screw shaft length of the extruder needs to be captured and the screw elements can be selected according to the 
characteristics represented in Table S1: 1) Conveying double-thread screw (C2F), 2. Conveying single screw (C1F), 3) Kneading disc (KD), or 4) Counter-flux single screw (CF1C), until the screw shaft length is completed.

\section{b. Process variables:}

i. Heating zone temperatures: 10 temperatures through TSE must be supplied.

ii. $\quad$ Feed rate $(\mathbf{Q c})$

iii. Screw speed (SS)

iv. Pressure (P)

4) Variable initialization. The variables are initialized with the values supplied in steps 2) and 3).

5) Calculation of geometrical parameters. Geometrical parameters are calculated according to length and geometrical configuration.

6) Residence time. Resident time is calculated according to element type: direct, inverse, or kneading disc.

7) Calculation of viscosity and shear rate parameters

8) Calculation of kinetic rate constants:

a. L, H and C.

9) Solution of overall model.

a. The model is solved using a series of CSTRs model and applying a material balance for the i-th reactor, applying Eq. (14).

b. Concentrations of L, H, C, X and G are calculated (Eqs. 15-20).

10) End of calculation procedure. 


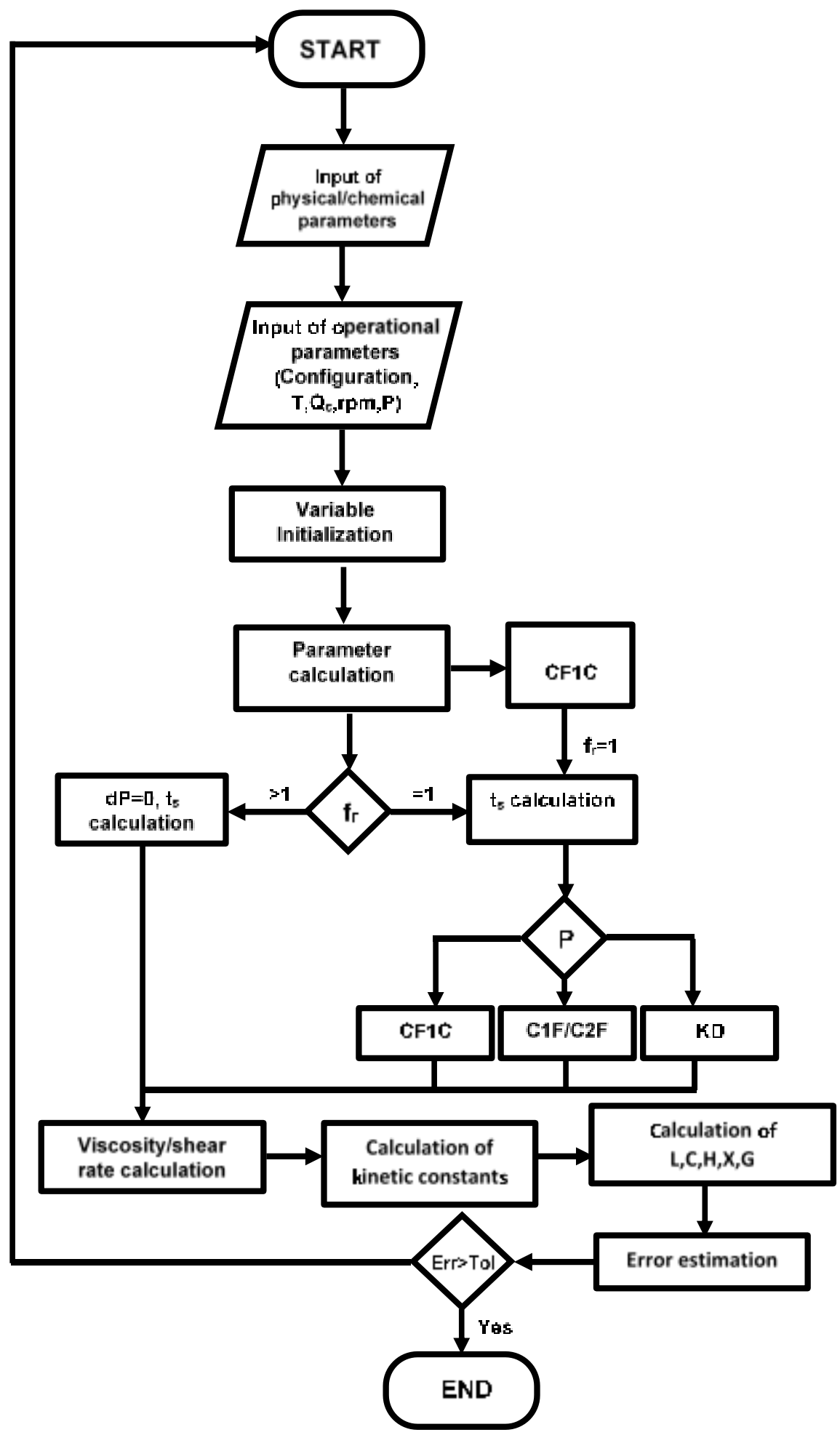

Error estimation

Figure S2. Calculation flow chart. 


\section{S3. Additional Results}

The relationship between length, number of screw elements, and residence time for the TSE used in this contribution is shown in Figure S3 of the SI. As expected, the relationships between length and number of elements, as well as residence time and number of elements, is linear. Still, Figure S3 is useful to visualize the length of each processing zone, and the evolution of residence time. It is observed that the feeding zone consists of about $10 \mathrm{screw}$ elements. The relevance of this first zone is $\mathrm{BAB}$ transportation and mechanical pretreatment. The second zone, where lignin deconstruction and partial cellulose and hemicellulose alkaline hydrolysis takes place, ${ }^{55,59}$ is the largest one, with about 15 elements. $\mathrm{H}_{3} \mathrm{PO}_{4}$ is subsequently added to neutralize the reacting biomass. This neutralization zone consists of 8 elements. Finally, the deconstructed and neutralized BAB is filtered. Although the liquid phase may contain some extracted cellulose and hemicellulose, or some monomeric sugars, in this work we only considered the solid phase.
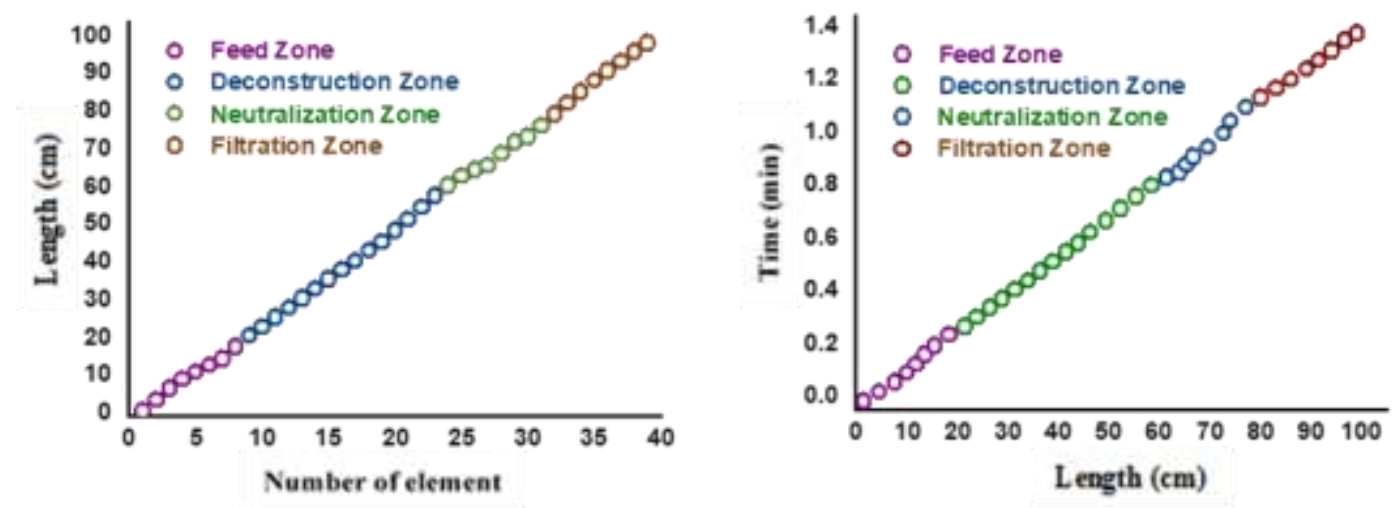

Figure S3. Relationship between extruder length and number of elements (left) and residence time versus length (right). Configuration and operation conditions are reported in experiment 1 (see Tables S2 and 2). 
NOMENCLATURE
Ab Cross section barrel surface $\left(\mathrm{m}^{2}\right)$
As Cross section screw barrel $\left(\mathrm{m}^{2}\right)$
B $\quad$ Pitch (m)
Be Equivalent Pitch for kneading disks
Bel Equivalent pitch (m)
C
Cellulose concentration (weight of cellulose (g) / weight of lignocellulosic material (g))
$\mathbf{C}_{\mathbf{L}} \quad$ Center to center distance between the screws (m)
$\mathbf{C}_{\mathbf{p}} \quad$ Specific heat capacity at constant pressure $\left(\mathrm{KJ} \mathrm{kg}^{-1} \mathrm{~K}^{-1}\right)$
DP
Concentration of decomposition products of xylose (weight of decomposition products $(\mathrm{g})$ / weight of lignocellulosic material $(\mathrm{g}))$
e Perpendicular flight width (m)
Fd Displacement flow shape factor (dimensionless)
F $\quad$ Pressure shape factor (dimensionless)
fr Filling ratio (dimensionless)
H
Hemicellulose concentration (weight of hemicellulose (g) / weight of lignocellulosic material $(\mathrm{g}))$
H Channel depth (m)
he Equivalent depth in kneading disks (m)
hel Depth of a rectangular channel (m)
hть Barrel heat-transfer coefficient $\left(\mathrm{W} \mathrm{m}^{-1} \mathrm{~K}^{-1}\right)$
hTs $\quad$ Screw heat transfer coefficient $\left(\mathrm{W} \mathrm{m}^{-1} \mathrm{~K}^{-1}\right)$ 
Lignin concentration (weight of lignin (g) / weight of lignocellulosic material

$\mathbf{L}$ (g))

L Length in $\mathrm{z}$ direction (m)

Lel Length of the rectangular channel (m)

Le Equivalent length

m Number of parallel channels (dimensionless)

m Rheology parameter “m” (Pa s)

N Screw rotational speed $\left(\mathrm{rad} \mathrm{s}^{-1}\right)$

n Rheology Parameter " $n$ ”

P Pressure (bar)

Qc Channel flow $\left(\mathrm{m}^{3} \mathrm{~s}^{-1}\right)$

QL $\quad$ Leakage flow $\left(\mathrm{m}^{3} \mathrm{~s}^{-1}\right)$

Qr Overflight flow $\left(\mathrm{m}^{3} \mathrm{~s}^{-1}\right)$

Re $\quad$ Screw radius $(\mathrm{m})$

$\mathbf{R}_{\mathbf{i}} \quad \operatorname{root} \operatorname{radius}(\mathrm{m})$

Sb Heat-exchange surface for the barrel $\left(\mathrm{m}^{2}\right)$

Ss Heat-exchange surface for the screw $\left(\mathrm{m}^{2}\right)$

T Temperature $\left({ }^{\circ} \mathrm{C}\right)$

$\mathbf{T}_{\mathbf{0}} \quad$ Feed temperature $\left({ }^{\circ} \mathrm{C}\right)$

$\mathbf{T}_{\mathbf{b}} \quad$ Temperature of barrel $\left({ }^{\circ} \mathrm{C}\right)$

$\mathbf{T}_{\mathbf{i}} \quad$ Sub-element Temperature $\left({ }^{\circ} \mathrm{C}\right)$

ts $\quad$ Residence time (min)

V(r) Velocity on radial position $\left(\mathrm{m} \mathrm{s}^{-1}\right)$ 


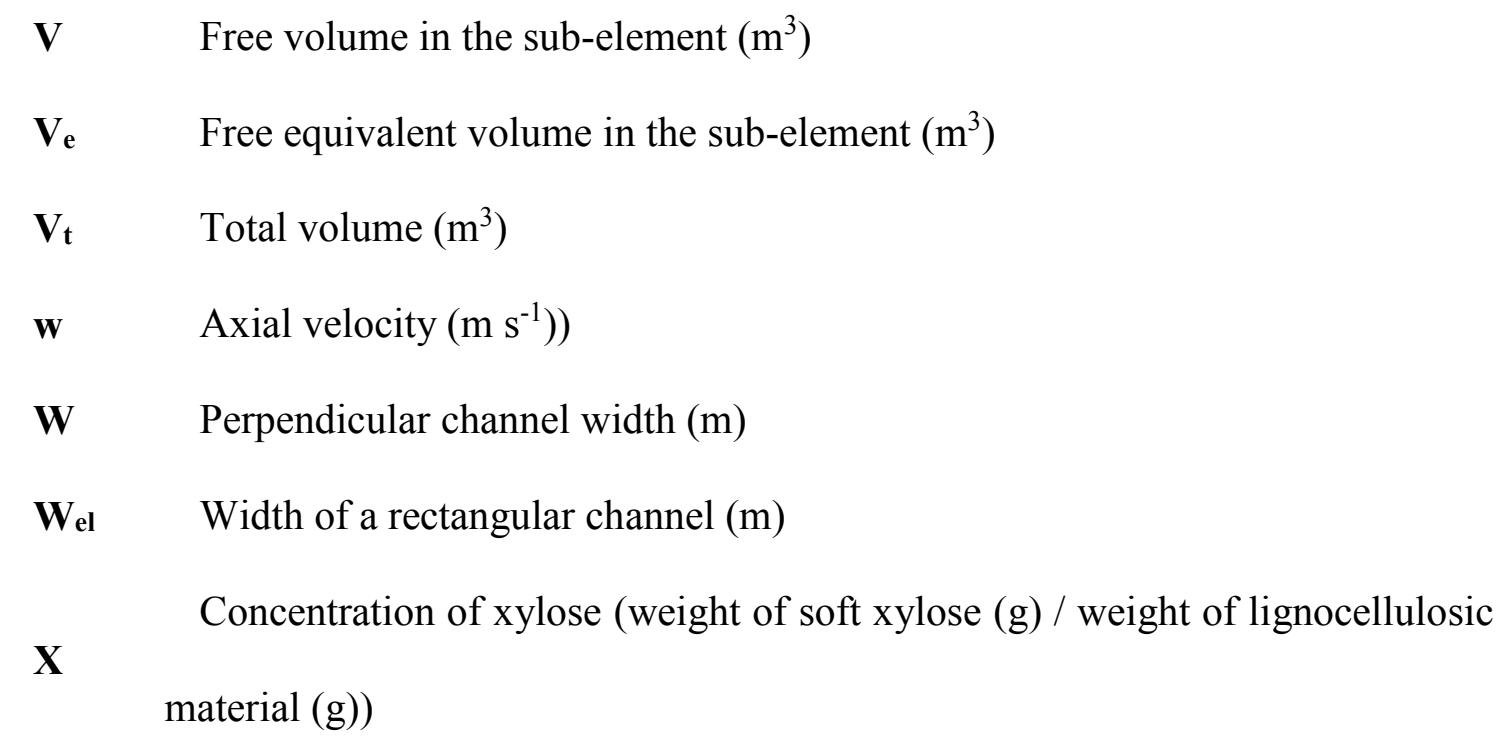

Y1

Concentration of soft cellulose concentration (weight of soft cellulose $(\mathrm{g}) /$ weight of lignocellulosic material (g))

Concentration of hard (weight of hard cellulose $(\mathrm{g}) /$ weight of lignocellulosic Y2 material $(\mathrm{g}))$

Concentration of glucose (weight of glucose (g) / weight of lignocellulosic material $(\mathrm{g}))$

Y4

Concentration of disaccharides (weight of disaccharides (g) / weight of lignocellulosic material $(\mathrm{g}))$

Y5

Concentration of glucosides (weight of glucosides (g) / weight of lignocellulosic material $(\mathrm{g}))$

Concentration of levoglucosane (weight of levoglucosane (g) / weight of Y6 lignocellulosic material $(\mathrm{g}))$

$\mathbf{z} \quad$ Axial channel width (m)

$\boldsymbol{\alpha} \quad$ Tip angle (radians)

$\boldsymbol{\pi}-\Delta \boldsymbol{\theta} \quad$ Staggering angle (radians) 


$\begin{array}{ll}\Delta \boldsymbol{\theta}_{\mathbf{C}} & \text { Angle of a C-shaped camera (radians) } \\ \Delta \boldsymbol{\theta}_{\mathbf{T}} & \text { Displacement angle (radians) } \\ \boldsymbol{\varphi} & \text { Helix angle (radians) } \\ \boldsymbol{\varphi}_{\mathbf{e}} & \text { Equivalent angle for kneading disks (radians) } \\ \boldsymbol{\gamma} & \text { Shear rate (Dimensionless) } \\ \boldsymbol{\eta} & \text { Viscosity }(\mathrm{Pa} \mathrm{s}) \\ \boldsymbol{\rho} & \left.\text { Density (g cm }{ }^{-3}\right) \\ \boldsymbol{\Omega} & \left.\text { Screw rotation speed ( } \mathrm{rad} \mathrm{s}^{-1}\right)\end{array}$

